\title{
Тетяна Солодовник
}

кандидат педагогічних наук, доцент, кафедра педагогіки і психології управління соціальними системами ім. академіка І.А. Зязюна, Національний технічний університет "Харківський політехнічний інститут"; Харків, Україна

ORCID: 0000-0002-7772.993878

E-mail: solodovnik_t_a@i.ua

\section{Жанна Богдан}

кандидат психологічних наук, доцент, кафедра педагогіки і психології управління соціальними системами ім. академіка І.А. Зязюна, Національний технічний університет “Харківський політехнічний інститут”; Харків, Україна

ORCID: 0000-0003-1560-9516

E-mail: janna.bogdan1979@gmail.com

\section{Наталія Середа}

кандидат мистецтвознавства, доцент, кафедра педагогіки і психології управління соціальними системами ім. академіка І.А. Зязюна, Національний технічний університет “Харківський політехнічний інститут”; Харків, Україна

ORCID: 0000-0001-8472-0117

E-mail: sereda.nataliia.khpi@gmail.com

\section{ГЕНДЕРНІ ВІДМІННОСТІ ОСОБИСТІСНИХ ХАРАКТЕРИСТИК ВІРТУАЛЬНОГО СПІЛКУВАННЯ МОЛОДІ СТУДЕНТСЬКОГО ВІКУ}

Анотація. У статті розглянуто певні особливості віртуального спілкування активних інтернет-користувачів студентського віку; проведено емпіричне дослідження; визначено гендерні відмінності особистісних характеристик молоді під час інтернет-комунікацій.

Ключові слова: спілкування, віртуальне спілкування, віртуальна реальність, інформаційні технології, гендер, гендерні відмінності, студентський вік, активні інтернет-корстувачі.

\section{Tetiana Solodovnyk}

Candidate of Pedagogical Sciences, Associate Professor, Department ofPpedagogy and Psychology of Social Systems Management of the academician I. Zyazyun, National Technical University «Kharkiv Polytechnic Institute»; Kharkiv, Ukraine ORCID: 0000-0002-7772.993878

E-mail: solodovnik_t_a@i.ua

(C) Тетяна Солодовник, Жанна Богдан, Наталія Середа, 2019 


\section{Zhanna Bogdan}

Candidate of Psychological Sciences, Associate Professor, Department ofPpedagogy and Psychology of Social Systems Management of the academician I. Zyazyun, National

Technical University «Kharkiv Polytechnic Institute»; Kharkiv, Ukraine

ORCID: 0000-0003-1560-9516

E-mail: janna.bogdan1979@gmail.com

\section{Nataliia Sereda}

Candidate of Art Sciences, Associate Professor, Department ofPpedagogy and Psychology of Social Systems Management of the academician I. Zyazyun, National Technical University «Kharkiv Polytechnic Institute»; Kharkiv, Ukraine

ORCID: 0000-0001-8472-0117

E-mail: sereda.nataliia.khpi@gmail.com

\section{GENDER DIFFERENCES OF PERSONAL CHARACTERISTICS BY VIRTUAL COMMUNICATION AMONG YOUNG STUDENTS}

Abstract. The article deals with certain features of virtual communication between active Internet users of student age; an empirical study was conducted; gender differences of personal characteristics by virtual communication among young students were determined.

Keywords: communication, virtual communication, virtual reality, information technologies, gender, gender differences, student age, active internet users.

Татьяна Солодовник, Жанна Богдан, Наталья Середа

\section{ГЕНДЕРНЫЕ ОТЛИЧИЯ ЛИЧНОСТНЫХ ХАРАКТЕРИСТИК ВИРТУАЛЬНОГО ОБЩЕНИЯ МОЛОДЕЖИІ СТУДЕНЧЕСКОГО ВОЗРАСТА}

Аннотация. В статье рассмотрены некоторые особенности виртуального общения активных интернет-пользователей студенческого возраста, проведены эмпирические исследования; определень гендерные различия личностных характеристик молодежи в интернет-коммуникациях.

Ключевье слова: общение, виртуальное общение, виртуальная реальность, информационные технологии, гендер, гендернье отличия, студенческий возраст, активнье интернет-пользователи.

\section{Tetiana Solodovnyk, Zhanna Bogdan, Nataliia Sereda}

An extended abstract of a paper on the subject of:

"Gender differences of personal characteristics by virtual communication among young students"

Problem setting. Today, over a billion people on our planet use the Internet. Computers and the Internet came into human life very quickly, sometimes displacing other spheres of life. This problem is particularly serious for young people, because they are, firstly, influenced by negative trends, and secondly, quickly adapt to and catch on 
everything new that modern scientific and technological progress offers.

Recent research and publications analysis. The works of E. Ilyin, Sh. Bern are dedicated to gender studies; various aspects of virtual communication were considered in the works of N. Grabar, O. Nemesh, G. Ostapenko, V. Posokhova; personal characteristics and gender aspects of communication between Internet users have been researched by such scientists as O. Goroshko, Z. Ryabikina and others.

Paper objective is to identify empirically and interpret the gender differences of personal characteristics by virtual communication among active Internet users of student age.

Paper main body. According to statistics, men are more likely to use computer technologies and the global network than women because, firstly, they are more versed in current scientific and technological advancements, and secondly, women have been forbidden to study and work for a long time. When choosing a future profession, women are more likely to choose humanities than men.

Studies of gender psychology confirm significant differences in the characteristics of male and female communications. Women during conversation are focused on receiving feedback from the interlocutor, establishing mutual understanding; they pay more attention to the appearance and facial expressions, while men's communication is aimed towards resolving specific matters. Virtual communication has many similarities with communication in the real world, but, at the same time there are many differences. First of all, it is mediated by a computer or other device, and the interaction takes place in virtual reality. A person has the opportunity to communicate without the presence of a partner, and does not communicate with the real person, but rather with someone whom the interlocutor imagines themselves to be and wants to represent. So not real people but those whom people pretend to be take part in communication.

Particular attention should be paid to social networks where so-called friendly communication or interest-based communication takes place. It seems that one has many friends and supporters, he/she is popular and sociable, but most often, this is a false idea, and in reality the person can be completely lonely. Virtual communication creates a sense of anonymity and security, you can be frank and bold in statements and judgments, provide false information, deceive, manipulate, impersonate other people, even of another gender.

The experimental study involved male and female students, active Internet users, in the number of 128 people (67 men and 61 women).

In order to identify gender differences of personal characteristics by virtual communication among students, the Sixteen Personality Factor Questionnare, 16 PF (R. Cattell) and the Diagnosis of emotional intelligence (N. Hall) were applied. After conducting an empirical research, a correlation between the personal characteristics of active Internet users of student age and gender was obtained.

Data obtained by R. Cattell's Sixteen Personality Factor Questionnare correspond to the normal distribution, so the method of one-way analysis of variance was used for calculating the level of significance of differences in the obtained indicators in two groups. We estimated the probability of differences by blocks of personal characteristics: communicative, intellectual, emotional.

Conclusions of the research. Male students who communicate in the Internet actively are distinguished by the following personal characteristics: a desire to communicate, courage and spontaneity in social contacts, a need for emotional connections but with a high focus on strengthening and maintaining their independence, dominance in relationships, 
emotional stability, high self-control, honesty, propensity to experimentation, initiative in relationships, initiative to control, management of nascent relationships and absolute rejection of control over oneself.

Female students, who are active Internet users, have a high orientation towards communication but with a tendency to adapt, dependence on the group, passivity in contact establishment, caution in choosing a partner, emotional instability, the

\section{Постановка проблеми в загальному вигляді та її зв'язок із важливими науковими чи практичними завданнями. Сьогодні} мережею Інтернет користується 4,39 мільярда населення нашої планети (за даними компаній We Are Social та Hootsuite) [1]. Комп'ютери i Інтернет дуже швидко увірвалися у життя людини, іноді виштовхуючи інші сфери життєдіяльності. Особливо серйозно ця проблема стосується молоді, оскільки молода людина, по-перше, піддається впливу негативних тенденцій, а по-друге, швидше пристосовується і розуміє усе нове, що пропонує сучасний науковотехнічний прогрес.

Звичайно, що не можна розглядати глобальну мережу тільки 3 негативної точки зору. Завдяки ній багато чого стало простішим i доступнішим для людей, зокрема спілкування 3 рідними й близькими, що знаходяться на великій відстані, навчальна інформація (підручники, посібники, довідники, статті, тести тощо), замовлення товарів і послуг, пошук та обмін інформацією професійного та ділового характеру, можливість відкрити власний бізнес, навчатися або працювати дистанційно.

Проте, поряд 3 тими позитивними змінами, що вніс в наше життя Інтернет, виникла значна кількість проблем, серед яких: шахрайство, шкідливий вплив на здоров'я, особливо дітей та підлітків, spontaneous behavior bordering on volatility, conservatism, lack of initiative in the relationship and expectation of the initiative from others, dependence on other people's opinion, which causes avoidance of responsibility.

It is revealed that women have a higher index of emotional intelligence than men, as well as its individual indicators, such as self-motivation, recognition of other people emotions.

Інтернет-залежність. На особливу увагу заслуговує проблема заміни живого спілкування віртуальним, в основному серед людей молодого віку. Доступність інформаційних технологій, інноваційних пристроїв (гаджетів), мережі Інтернет дозволяють спілкуватися будь 3 ким у будь-який час майже без обмежень; така кількість потенційних співрозмовників створює уявлення про широке коло знайомих та друзів різного віку, статі, професії, соціального статусу. У людини виникає почуття, що вона $\epsilon$ частиною спільноти, і частково, а іноді й повністю, віртуальне спілкування замінює реальне. На жаль, такі тенденції вже мають шкідливе розповсюдження, коли людина, найчастіше молода, повністю занурюється у віртуальний світ із уявними друзями, і як наслідок виникають проблеми у реальному житті, неможливість налагоджувати контакти й спілкуватися з живими людьми.

Особливої актуальності проблеми віртуального спілкування набувають у зв'язку 3 активним запровадженням дистанційних технологій до системи сучасної освіти, а також переходом комунікацій різних видів і напрямів у віртуальний світ. Так, за ініціативи президента України прискорено процес діджіталізації комунікацій між суспільством та владою (проекти «Країна в смартфоні», «Електронний уряд» тощо). 
Аналіз останніх досліджень i публікацій, у яких започатковано розв'язання цієї проблеми i на які спирається автор. Дослідженню гендера присвячені роботи Є. Ільїна, Ш. Берна [ 2, 3], різні аспекти віртуального спілкування розглянуто у працях Н. Грабара, О. Немеш, Г. Остапенко, В. Посохової [4, $5,6,7]$, особистісні характеристики та гендерні аспекти спілкування інтернеткористувачів досліджували такі науковці, як О. Горошко, Рябікіна 3. [8, 9] та інші. Гендерні відмінності Інтернеткористувачів та особливості їхнього віртуального спілкування $\epsilon$ темою досліджень зарубіжних вчених, зокрема Jackson L., Ervin K. \& Gardner P.; Ono H. \& Zavodny M.; Weiser E.; Herring S. тощо $[10,11,12,13]$.

Виділення не вирішених раніше частин загальної проблеми, котрим присвячується дана стаття. На сьогодні існують публікації, в яких розглядаються проблеми взаємодії та комунікацій у віртуальному просторі різних соціальних груп, проте досліджень, присвячених визначенню гендерних відмінностей особистісних характеристик віртуального спілкування активних інтернеткористувачів студентського віку недостатньо.

Формулювання цілей статті (постановка завдання): за результатами використання емпіричних методів наукового пізнання визначити гендерні відмінності особистісних характеристик віртуального спілкування активних інтернет-користувачів студентського віку.

Виклад основного матеріалу дослідження 3 повним обгрунтуванням отриманих наукових результатів. За статистикою чоловіки частіше користуються комп'ютерними технологіями та глобальною мережею, ніж жінки, оскільки по-перше, більше розуміються на сучасних досягненнях науково-технічного прогресу, по-друге, тривалий історичний проміжок часу жінкам було заборонено займатися наукою та працювати, до теперішнього часу жінки під час вибору майбутньої професії частіше обирають гуманітарні спеціальності, ніж чоловіки.

У професійній діяльності чоловіки також більше користуються комп'ютерними та інформаційними технологіями, швидше й 3 більшою легкістю опановуючи нові програми, електронні пристрої. Чоловіки, на відміну від жінок, швидше знаходять необхідну інформацію, користуються Інтернеткомунікаціями, здійснюють придбання товарів через Інтернет-магазини, і взагалі більше часу проводять в Інтернетпросторі. Комп'ютерні ігри також здебільшого розраховані на чоловічу аудиторію, жінки більше часу перебувають на різноманітних форумах та у соціальних мережах, спілкуючись 3 віртуальними співрозмовниками та однодумцями.

Спілкування є особливим видом діяльності людини, має складну структуру та виконує багато функцій, таких як комунікативна, когнітивна, емотивна, естетична тощо, як зазначає О. Леонтьєв, «будь-яка людська діяльність неможлива поза спілкуванням». Спілкування є важливою соціальною потребою людини для створення й підтримки дружніх, сімейних, професійних зв'язків, для приналежності до якоїсь групи, для відчуття єдності з іншими людьми.

У межах цієї публікації ми дотримуємося визначення, що спілкування - «це складне соціальнопсихологічне явище, яке $є$ однією з умов формування та розвитку особистості, ефективною взаємодією між людьми у всіх сферах життєдіяльності, пов'язаною $з$ почуттями, емоціями, переживаннями, роздумами» [14, с. 283]. Будь-яке спілкування включає в себе не тільки комунікативне повідомлення, а й емоційну-чуттєву сферу особистості: 
радість, гнів, подив, захопленість, відразу. У комунікативному акті обов'язково присутнє ставлення до співрозмовника, до якого воно адресоване. Навіть у ділових та професійних комунікаціях повністю виключити емоційні реакції співрозмовників майже неможливо.

За результатами аналізу можна стверджувати, що спілкування чоловіків і жінок має достатньо відмінностей. Це обумовлено такими факторами як психофізіологічні особливості, соціокультурні моделі, гендерні стереотипи та соціальні ролі. Жіноче спілкування характеризується емоційністю, емпатією, образністю, насиченістю епітетами. Чоловічі повідомлення більш конкретні та інформативні, хоча теж можуть демонструвати певні емоційні стани, наприклад, агресивність.

Дослідження гендерної психології підтверджують суттєві відмінності у характеристиці чоловічих та жіночих комунікацій. Жінки у спілкуванні спрямовані на отримання зворотного зв'язку від співрозмовника, встановлення взаєморозуміння, більше звертають увагу на зовнішність та вираз обличчя, тоді як чоловічому спілкуванню притаманне вирішення конкретних справ. Звичайно, що існують традиційні гендерні ролі, суспільні погляди на чоловічу та жіночу поведінку, на те, які види діяльності більше підходять чоловікам, а які жінкам, так звані «чоловічі» й «жіночі» професії, $з$ яких витікають особливості й у спілкуванні. Чоловікам притаманно спілкуватися 3 людьми свого кола або 3 людьми, які мають статус вищий за свій, проте як жінок більше приваблює здатність довіряти та інтимність у спілкуванні як із співрозмовниками своєї статі, так i 3 протилежної. Це підтверджують дослідження О. Бодальова, «...у жінок характеристики, в яких проявляється ставлення людини до інших людей, на шкалі цінностей займають більш високе місце, ніж $\mathrm{y}$ чоловіків. Вони для жінок суб'єктивно більш значущі» [15, с. 71].

Також існують відмінності у спілкуванні чоловіків та жінок мовностилістичного характеру. На думку Л. Корнєвої, ці відмінності стосуються, по-перше, комунікативної поведінки загалом та виявляються в типових стратегіях і тактиках ведення розмови, виборі тем спілкування та способів досягнення успіху в ньому, ступені впевненості, ввічливості та кооперативності висловлювання тощо. По-друге, відмінності спостерігаються на всіх рівнях мови: фонологічному, лексичному, граматичному [16, с. 108].

Різні стилі спілкування обумовлені не тільки відмінностями у фізіології i психіці чоловіків та жінок, а й гендерними стереотипами, що склалися у суспільстві: комунікативна поведінка, манера подання повідомлень, співчуття, наполегливість або агресивність, стриманість або емоційність. Така поведінка людини обумовлена не тільки гендерними відмінностями й різними соціальними факторами, такими як соціокультурне та професійне оточення, статусні відносини, родинні взаємозв'язки, особливості виховання тощо.

Віртуальне спілкування має багато спільних рис 3 реальним, проте й існує багато відмінностей: передусім спілкування опосередковане комп'ютером або іншим пристроєм, взаємодія відбувається у віртуальній реальності. Людина має можливість спілкуватися без присутності партнера по спілкуванню, і здійснює комунікацію не 3 реальною людиною, а 3 тим, ким себе співрозмовник уявляє і презентує, тобто взаємодіють не реальні особистості, а ті, за кого вони себе видають.

Спілкування виконує три основні функції: комунікативну, перцептивну й інтерактивну. Під час віртуального 
спілкування на перше місце виходить комунікативна функція, а інтерактивна й перцептивна функції спотворюються, а, іноді, навіть нівелюються. Таким чином, у людини, особливо у молодої, зменшуються соціальні контакти, що може призвести до проблем зі спілкуванням у реальному житті, тобто проявляється високий рівень гіпертрофованої інтроверсії. Як негативний наслідок, може виникати Інтернет-залежність й відсутність можливості вести активне соціальне життя. В країнах $з$ високо розвиненими Інтернет-технологіями простежується проблема зменшення міжособистісних стосунків у реальному житті, що призводить до відсутності статеворольових відносин.

Незважаючи на те, що молода людина щоденно проводить багато часу в Інтернеті, і це не тільки спілкування у соціальних мережах (Facebook, Twitter, Instagram й інші) і месенджерах (Viber, Telegram), а й навчальна або професійна діяльність (електронні підручники, посібники, онлайн-курси, наукові статті, навчальні програми, відеоексурсії, електронне спілкування тощо), проте взаємодія 3 комп'ютером та Інтернет, навіть у межах особистісного саморозвитку, не зменшує негативного впливу на людину.

Особливої уваги заслуговує спілкування у соціальних мережах, так зване дружне спілкування або спілкування за інтересами. Виникає відчуття, що людина має багато друзів та прихильників, створюється враження, що людина $\epsilon$ затребуваною i комунікабельною, проте найчастіше воно хибне, й у реальному світі людина може бути зовсім самотньою. Під час віртуального спілкування виникає відчуття анонімності та безпеки, можна бути відвертим та сміливим у висловлюваннях та судженнях, надавати хибну інформацію, обманювати, маніпулювати, видавати себе за іншу людину, навіть іншої статі. Така безкарність тягне за собою вседозволеність та безвідповідальність, замість прояву власного «Я» формується віртуальна особистість; в реальному світі це може провокувати девіантну поведінку.

Віртуальне спілкування, як i реальне, має свої особливості у жінок і чоловіків. Жінки у віртуальному світі більш довірливі й вразливі, також прагнуть виражати почуття й емоції, бажають отримувати підтримку й схвалення, більш схильні до романтичного погляду на події, може навіть виникати віртуальна закоханість або віртуальний роман.

На відміну від жінок, чоловіки менше уваги приділяють соціальним мережам та різноманітним Інтернетчатам, витрачаючи час на комп'ютерні розваги, і мають менше схильностей до романтичних захоплень у віртуальному світі.

3 метою виявлення гендерних відмінностей особистісних характеристик віртуального спілкування молодих людей ми провели експериментальне дослідження, у якому взяли участь особи чоловічої та жіночої статі віком від 18 до 25 років, які є студентами харківських закладів вищої освіти, активні Інтернеткористувачі, в кількості 128 осіб (67 чоловіків та 61 жінка). До цієї групи респондентів було віднесено студентську молодь за такими критеріями:

- висока частота відвідувань своїх сторінок у соціальних мережах,

- значна кількість (не менше трьох) підтримуваних акаунтів,

- захопленість різноманітною діяльністю в соціальних мережах,

- надання публічної інформації в мережі,

- наявність публікацій медіаконтенту та фотоматеріалів. 
3 метою виявлення гендерних відмінностей особистісних характеристик активних Інтернет-користувачів студентського віку було застосовано наступні методики: 16-факторний опитувальник особистості Р. Кеттелла та методику діагностики емоційного інтелекту Н. Холла $[17,18]$. Після проведення емпіричного дослідження було виявлено взаємозв'язок особистісних характеристик активних Інтернет-користувачів студентського віку зі статтю.

Отримані дані за багатофакторною особистісною методикою Р. Кеттелла відповідають закону нормального розподілення, тому було використано метод однофакторного дисперсійного аналізу, за допомогою якого обчислювався рівень значущості відмінностей отриманих показників у двох групах. Вірогідність розбіжностей оцінювалася нами за блоками особистісних характеристик: комунікативні, інтелектуальні, емоційні.

Чоловікам студентського віку, які $\epsilon$ активними Інтернет-користувачами, властиве виражене прагнення до спілкування, комунікабельність (чинник $\mathrm{A}: \mathrm{m}=13,78, \mathrm{p} \leq 0,05)$, сміливість (чинник $\mathrm{H}: \mathrm{m}=14,51, \mathrm{p} \leq 0,05)$ і спонтанність (чинник $\mathrm{N}$ : $\mathrm{m}=10,97, \mathrm{p} \leq 0,05) \quad \mathrm{y}$ соціальних контактах, прагнення до вибудовування тісних емоційних зв'язків, які грунтуються на симпатії та прихильності (чинник $\mathrm{F}: \mathrm{m}=12,93$, $\mathrm{p} \leq 0,05)$. При цьому вони орієнтовані на зміцнення і підтримку своєї незалежності від групи (чинник $\mathrm{Q} 2: \mathrm{m}=9,96, \mathrm{p} \leq 0,05$ ), що може проявлятися в домінантності, прагненні до лідерства і агресивності в стосунках (чинник $\mathrm{E}: \mathrm{m}=12,99, \mathrm{p} \leq 0,05$ ). Їм притаманні емоційна стійкість (чинник 3: $\mathrm{m}=15,96, \quad \mathrm{p} \leq 0,05), \quad$ високий самоконтроль, сила волі (чинник Q3: $\mathrm{m}=12,01, \mathrm{p} \leq 0,05$ ), сумлінність (чинник
G: $\quad \mathrm{m}=14,87, \quad \mathrm{p} \leq 0,05)$, неконсервативність, схильність до експериментування, пізнання нового (чинник $\mathrm{Q} 1: \mathrm{m}=11,14, \mathrm{p} \leq 0,05$ ). Чоловіки студентського віку демонструють високу пізнавальну активність, легко встановлюють та підтримують контакти в просторі міжособистісного спілкування. Ініціюють управління стосунками, що виникають у соціальних мережах.

Жінкам студентського віку, які є активними Інтернет-користувачами, властива висока орієнтованість на спілкування (чинник А: $\mathrm{m}=10,25$, $\mathrm{p} \leq 0,05)$, але зі схильністю до пристосування (фактор $\mathrm{E}: \mathrm{m}=8,92$, $\mathrm{p} \leq 0,05)$, залежно від групи (чинник Q2: $\mathrm{m}=7,19, \quad \mathrm{p} \leq 0,05) ; \quad$ пасивність $\mathrm{y}$ встановленні контактів 3 очікуванням ініціативи від інших (чинник $\mathrm{H}$ : $\mathrm{m}=$ 11,58 , стін 5, p <0,05); обережність i вибірковість у виборі партнера (чинник $\mathrm{F}: \mathrm{m}=10,28, \quad \mathrm{p} \leq 0,05) ; \quad$ емоційна нестійкість (фактор C: $\mathrm{m}=10,87$, $\mathrm{p} \leq 0,05)$, природність і безпосередність поведінки (фактор $\mathrm{N}$ : $\mathrm{m}=10,16$, $\mathrm{p} \leq 0,05$ ) межує 3 непостійністю (фактор $\mathrm{G}: \quad \mathrm{m}=10,68, \quad \mathrm{p} \leq 0,05) \quad \mathrm{i}$ недисциплінованістю (фактор Q3: $\mathrm{m}=11,01, \mathrm{p} \leq 0,05) ;$ консервативність, уникнення експериментування (фактор $\mathrm{Q} 1: \mathrm{m}=8,55, \mathrm{p} \leq 0,05)$. Отже, жіноча група демонструє високу орієнтованість та залежність від думки інших людей, жінки більше схильні переживати минуле, ніж чоловіки, проявляють пасивність та неготовність контролювати стосунки.

Для виявлення здатності розуміти ставлення особистості, що репрезентується в емоціях, і управляти емоційною сферою на основі ухвалення рішень було використано діагностичну методику емоційного інтелекту Н. Холла. Отримані результати наведені в таблиці 1. 
ІНФОРМАЦІЙНІ ТЕХНОЛОГІЇ І ЗАСОБИ НАВЧАННЯ В ПРОФЕСІЙНІЙ

ПІДГОТОВЦІ МАЙБУТНІХ ФАХІВЦІВ

Таблиця 1 - Показники емоційного інтелекту чоловіків та жінок студентського віку за методикою Н. Холла

\begin{tabular}{l|c|c|c|c|c|c}
\hline \multirow{2}{*}{ Шкали } & \multicolumn{2}{|c|}{ Чоловіки $(\mathrm{n}=67)$} & \multicolumn{2}{c|}{ Жінки $(\mathrm{n}=61)$} & \multicolumn{2}{c}{ Знач. відмін } \\
\cline { 2 - 8 } & $\mathrm{cp}$. & $\mathrm{c}$. відх. & $\mathrm{cp.}$ & $\mathrm{c}$. відх. & t-крит. & знач. \\
\hline Емоційна обізнаність & 11,48 & 2,94 & 12,93 & 3,45 & - & - \\
\hline $\begin{array}{l}\text { Управління своїми } \\
\text { емоціями }\end{array}$ & 11,10 & 2,86 & 12,24 & 3,19 & - & - \\
\hline Самомотивація & 10,03 & 5,11 & 13,22 & 2,89 & $-3,348$ & 0,001 \\
\hline Емпатія & 10,90 & 4,93 & 13,49 & 3,26 & $-2,673$ & 0,009 \\
\hline $\begin{array}{l}\text { Розпізнавання емоцій інших } \\
\text { людей }\end{array}$ & 5,97 & 5,31 & 9,88 & 3,96 & $-3,581$ & 0,001 \\
\hline $\begin{array}{l}\text { Інтегративний рівень } \\
\text { емоційного інтелекту }\end{array}$ & 49,48 & 16,91 & 61,76 & 14,48 & $-3,312$ & 0,001
\end{tabular}

За шкалою «Емоційна обізнаність» в обох групах виявлений середній рівень: середній бал у чоловіків складає 11,48 ; і у жінок - 12,93 бали. За шкалою «Управління своїми емоціями» в обох групах виявлений середній рівень: середній бал у чоловіків - 11,10; і у жінок - 12,24 бали. За шкалою «Самомотивація» в обох групах виявлений середній рівень: середній бал у чоловіків - 10,03; і у жінок - 13,22 бали. За шкалою «Емпатія» в обох групах виявлено середній рівень: середній бал у чоловіків - 10,90; і у жінок - 13,49. За шкалою «Розпізнавання емоцій інших людей» середній рівень виявлений у жіночій групі $(\mathrm{M}=9,88)$, тоді як $\mathrm{y}$ чоловічій групі відзначається низький рівень $(\mathrm{M}=5,97)$. За шкалою «Інтеграційний рівень емоційного інтелекту» в обох групах виявлений середній рівень: середній бал у чоловіків 49,48 бала, і у жінок - 61,76.

Висновки 3 даного дослідження та перспективи подальших розвідок у даному напрямку. Таким чином, підсумовуючи проведений теоретичний аналіз та отримані емпіричні дані, можна стверджувати, що гендерні відмінності особистісних характеристик віртуального спілкування молоді студентського віку існують.
Чоловіків студентського віку, які активно спілкуються в Інтернет-просторі, відрізняють наступні особистісні характеристики: прагнення до спілкування, сміливість і спонтанність в соціальних контактах, прагнення до емоційних зв'язків, але 3 високою орієнтацією на зміцнення i підтримку своєї незалежності, домінантність у стосунках; емоційна стійкість, високий самоконтроль, сумлінність; схильність до експериментування; ініціативність у стосунках; ініціатива в контролі, управління взаємовідносинами, що складаються, і категоричне неприйняття контролю над собою.

Жінкам студентського віку, які є активними Інтернет-користувачами, властива висока орієнтованість на спілкування, але зі схильністю до пристосування, залежність від групи, пасивність у встановленні контактів, обережність у виборі партнера; емоційна нестійкість, безпосередність поведінки, яка межує 3 непостійністю; консервативність; відсутність ініціативи в стосунках i очікування ініціативи від інших, залежність від думки оточуючих, що обумовлює уникнення відповідальності.

Виявлено, що жінки в порівнянні 3 чоловіками мають більш високий 
загальний показник емоційного інтелекту, а також високий рівень виявлено у його окремих показників, таких як самомотивація, розпізнавання емоцій інших людей.

\section{Список літератури:}

1. Digital in 2019: Essential insights into how people around the world use the Internet, mobile devices, social media, and ecommerce. Access mode: https://wearesocial.com/global-digitalreport-2019

2. Ильин, Е.П. (2010) Пол и гендер. СПб., 688 с.

3. Шон Берн (2004) Гендерная психология. СПб.: Прайм-ЕВРОЗНАК,. $320 \mathrm{c}$.

4. Грабар, Н.Г. (2012) Соціальнопсихологічні проблеми спілкування у віртуальній реальності. Бібліотекознавство. Документознавство. Інформологія. № 3-4. С. $82-85$.
5. Немеш,
O.M.

Інформаційно-реконструктивні технології у становленні особистості: психологічний вимір. Fundamental and applied reseaches in practice of leading scientific schools. Publishing office: Accent Graphics Communications. Hamilton, ON,. Issue 1 (7). C. 124 - 142.

6. Остапенко, Г.I. (2013) Особливості віртуального спілкування молоді в комунікаційному середовищі мережі інтернет. СВIT соціальних комунікацій. Т 10. С. 113 - 117.

7. Посохова, В.В. (2013) Стилі онлайн спілкування інтернет-користувачів в повсякденній мережній діяльності. Теоретичні $i$ прикладні проблеми психології. № 3. С. $211-215$.

8. Горошко, О. I. (2009) Гендерна самоідентифікація у віртуальному просторі: спроба рефлексії. Проблеми самоідентифікаиії українського суспільства: політичні,
У подальших дослідженнях було б доцільним розглянути проблеми гендерних відмінностей віртуального спілкування з точку зору різних вікових груп, різного рівня освіти та соціального статусу Інтернет-користувачів.

економічні, сочіальні та культурні аспекти. К.: Національна академія управління. С. 193 - 196.

$$
\text { 9. Рябикина, З.И. }
$$

Взаимосвязь личностных характеристик пользователей социальных сетей интернета с особенностями их активности в сети. Научный журнал КубГАУ. №109 (05). C. $1-17$.

10. Jackson, L.A., Ervin, K.S. \& Gardner, P.D. et al. (2001) Gender and the Internet: Women Communicating and Men Searching. Sex Roles. 44: 363. Access mode: https://doi.org/10.1023/A:1010937901821

11. Ono, Hiroshi \& Zavodny, Madeline (2003) Gender and the Internet. Social Science Quarterly. vol. 84. no. 1. pp. 111 - 121 . Access mode: www.jstor.org/stable/42955858.

12. Weiser, Eric B. (2000) Gender Differences in Internet Use Patterns and Internet Application Preferences: A TwoSample Comparison. Behavior. Volume 3. Number 2. pp 167 - 178

13. Herring, Susan (2003) Gender and Power in Online Communication. The handbook of language and gender. pp $202-$ $228 . \quad$ Access mode: https://www.researchgate.net/publication/31 3001298_Gender_and_Power_in_Online_Co mmunication

$$
\text { 14. Андреева, Г.М. (1998) }
$$

Социальная психология: учеб. для высших учебных заведений. М.: Аспект Пресс, 376 с.

15. Бодалев, А.А. (1995) Личность и общение. М.: Международная педагогическая академия, $328 \mathrm{c}$.

16. Корнєва, Л. (2013) Гендерний аспект комунікації. Філологічні науки. № 13. C. $106-113$. 
17. Капустина, А. Н. (2001)

Многофакторная личностная методика Р. Кеттелла. Практикум по психодиагностике. СПб. : Речь, 112 с.

18. Тест на эмоциональный интеллект (Тест EQ) [Електронний pecypc]. Режим доступу: https://psycabi.net/testy/21-emotsionalnyjintellekt-eq

\section{References:}

1. Digital in 2019: Essential insights into how people around the world use the Internet, mobile devices, social media, and ecommerce. Access mode: https://wearesocial.com/global-digitalreport-2019

2. Il'in, E.P. (2010) Pol i gender. [Sex and gender]. SPb., 688 p. [in Russian]

3. Shon Bern (2004) Gendernaja psihologija. [Gender psychology]. SPb.: Prajm-EVROZNAK,. 320 p. [in Russian]

4. Hrabar, N.H. (2012) Sotsial'nopsykholohichni problemy spilkuvannia $u$ virtual'nij real'nosti. []. Bibliotekoznavstvo. Dokumentoznavstvo. Informolohiia. № 3 4. P. 82 - 85. [in Ukrainian]

5. Nemesh, O.M. (2015) Informatsijno-rekonstruktyvni tekhnolohii $u$ stanovlenni osobystosti: psykholohichnyj vymir. []. Fundamental and applied reseaches in practice of leading scientific schools. Publishing office: Accent Graphics Communications. Hamilton, ON,. Issue 1 (7). P. 124 - 142. [in Ukrainian]

\section{Ostapenko, H.I.}

Osoblyvosti virtual'noho spilkuvannia molodi $v$ komunikatsijnomu seredovyschi merezhi internet. []. SVIT sotsial'nykh komunikatsij. $\mathrm{T}$ 10. P. $113-117$. [in Ukrainian]

7. Posokhova, V.V. (2013) Styli onlajn spilkuvannia internet-korystuvachiv $v$ povsiakdennij merezhnij diial'nosti. []. Teoretychni i prykladni problemy psykholohii. № 3. P. $211-215$. [in Ukrainian]
8. Horoshko, O. I. (2009) Henderna samoidentyfikatsiia u virtual'nomu prostori: sproba refleksii. []. Problemy samoidentyfikatsii suchasnoho ukrains'koho suspil'stva: politychni, ekonomichni, sotsial'ni ta kul'turni aspekty. K.: Natsional'na akademiia upravlinnia. P. 193 196. [in Ukrainian]

$$
\text { 9. Rjabikina, Z.I. }
$$

Vzaimosvjaz' lichnostnyh harakteristik pol'zovatelej social'nyh setej interneta s osobennostjami ih aktivnosti $v$ seti. [The relationship of the personal characteristics of users of social networks of the Internet with the features of their activity on the network]. Nauchnyj zhurnal KubGAU. №109 (05). P. 1 - 17. [in Russian]

10. Jackson, L.A., Ervin, K.S. \& Gardner, P.D. et al. (2001) Gender and the Internet: Women Communicating and Men Searching. Sex Roles. 44: 363. Access mode: https://doi.org/10.1023/A:1010937901821

11. Ono, Hiroshi \& Zavodny, Madeline (2003) Gender and the Internet. Social Science Quarterly. vol. 84. no. 1. pp. 111 - $121 . \quad$ Access mode: www.jstor.org/stable/42955858.

12. Weiser, Eric B. (2000) Gender Differences in Internet Use Patterns and Internet Application Preferences: A TwoSample Comparison. Behavior. Volume 3. Number 2. pp 167 - 178

13. Herring, Susan (2003) Gender and Power in Online Communication. The handbook of language and gender. pp $202-$ 228. Access mode: https://www.researchgate.net/publication/31 3001298_Gender_and_Power_in_Online_Co mmunication

$$
\text { 14. Andreeva, G.M. (1998) }
$$

Social'naja psihologija: ucheb. dlja vysshih uchebnyh zavedenij. [Social Psychology: Textbook. for higher education]. M.: Aspekt Press, 376 p. [in Russian]

15. Bodalev, A.A. (1995) Lichnost' $i$ obshhenie. [Personality and Communication]. M.: Mezhdunarodnaja 
pedagogicheskaja akademija, 328 p. [in Russian]

16. Kapustina,

A. $\mathrm{N}$.

N. (2001)

Mnogofaktornaja lichnostnaja metodika $R$. Kettella. [The multifactorial personality technique of R. Kettell]. Praktikum po psihodiagnostike. SPb. : Rech', 112 p. [in Russian]
17. Kornieva, L. (2013) Hendernyj aspekt komunikatsii. []. Filolohichni nauky. № 13. P. 106 - 113 [in Ukrainian]

18. Test na jemocional'nyj intellekt (Test EQ). [Emotional Intelligence Test (EQ Test)]. Access mode: https://psycabi.net/testy/21-emotsionalnyjintellekt-eq [in Russian]

Стаття надійшла до редколегї 10.09.2019 